\title{
Field Evaluation of Selected Botanicals and Fungicides for the Management of Alternaria Blight of Cluster Bean
}

\author{
Satish Sharma*, Reeti singh and Ajay Kumar \\ Department of Plant Pathology-College of Agriculture, R.V.S.K. V.V. Gwalior, (M.P), India \\ *Corresponding author
}

\begin{tabular}{|l||}
\hline K e y w o r d s \\
Alternaria \\
cucumerina var. \\
cyamopsidis, \\
Botanical, \\
Fungicide \\
management \\
\hline Article Info \\
\hline $\begin{array}{l}\text { Accepted: } \\
\text { 11 June } 2020 \\
\text { Available Online: } \\
\text { 10 July } 2020\end{array}$ \\
\hline
\end{tabular}

A B S T R A C T
Cluster bean [Cyamopsis tetragonoloba (L.)Taub.] is an important arid legume crop. It is commonly called as Guar. Cluster bean is grown for different purposes viz., vegetable (pods), green fodder, green manure, straw, guar gum, seed production, cattle fodder and increase soil fertility (Yogi et al., 2016).effect of different weather parameters on disease development and effective management of the disease through plant extracts and fungicides. In field study, the efficacy of laboratory effective treatments was again evaluated. Allium серa(bulb extract) showed minimum per cent disease intensity against Alternaria blight disease on leaves with maximum yield $(26.66 \mathrm{q} / \mathrm{ha})$ of Cluster bean. The maximum PDI and minimum yield (15.44 q/ha) of cluster bean was showed by Cassiatora. Carbendazim+Mancozeb combination showed the minimum PDI 14.50 after 75 DAS against Alternaria blight disease of A. c. var.cyamopsidis on the leaves and maximum yield $(26.33 \mathrm{q} / \mathrm{ha})$ was obtained by this combination. In-vivo all the botanicals significantly reduced the per cent disease intensity of Alternaria blight of Cluster bean. Among the foliar applied botanicals (A. серa) and fungicide (Carbandazim+Mancozeb) were found best insignificantly reducing the Alternaria blight disease. In the field study, Allium cepa leaf extract @ 20\% concentration and Carbendazim (0.1 per cent) + Mancozeb ( 0.2 per cent) concentration were found very effective in reducing Alternaria blight and enhancing the yield of Cluster bean. The leaf extract of botanicals seems to be an alternate to the fungicides for an eco-friendly management of Alternaria blight disease.

\section{Introduction}

Alternaria spp. are economically important pathogens widely distributed throughout the world and cause devastating disease on field crops. Alternaria leaf blight is a common disease in guar-growing area of western India and Pakistan. Severe Alternaria blight of cluster bean was also reported from Pusa and
Madras (Ambesh et al., 2014). Primary methods of controlling Alternaria leaf blight include preventing long periods of wetness on the leaf surface, cultural scouting, sanitation, and development of the host plant resistant with the application of fungicides (Kirk et al., 2001 and Namanda et al., 2004). In recent years, an increasing consciousness about environmental pollution due to pesticides and 
development of fungicide-resistant strain in plant pathogens has challenged the plant pathologists to search for non-toxic fungicides for substituting the recommended chemicals. This is the most cost effective and ecofriendly management strategy selecting the genotypes possessing the resistant/tolerant reaction against the disease. Studies conducted on Blight of guar and its various aspects indicated that there are lot of gaps in the understanding of the disease, the pathogen and the control aspects and very meagre information is available on these aspects. Hence, a thorough investigation is required.

\section{Materials and Methods}

The present investigation was carried out on disease survey, symptomatology, suitable media for mycelial growth, biochemical test, variability, epidemiological effect, screening of different genotypes of Cluster bean for resistant reaction, control and management aspects against Alternaria blight of Cluster bean.

For the evaluation of selected botanicals and fungicides for the management of Alternaria blight of Cluster beanunder field condition, the effective 16 treatments; botanicals@20 $\%$ concentration and fungicides @ $0.1 \%$ for systemic and $0.2 \%$ for non systemic were used for foliar spray. The experiment was conducted in the field during Kharif season of the year 2016 and 2017. The seeds of Alternaria blight susceptible variety (Cluster bean cultivar M83) were sown in experimental fields in the RBD with four replications. The first spray was done just after the appearance of the disease and subsequent two sprayings were given at an interval of 15 days. Standard agronomical practices were followed as per recommendations. Observations on disease intensity were recorded when plants reached at the physiological maturity.

\section{Results and Discussion}

The botanicals (Allium cepa, Azadirachta indica, Calotropis procera, Cassia fistula, Cassia tora, Eucalyptus globulus and Parthenium hysterophorus) and fungicides (Carbendazim, Carbendazim+Mancozeb, Kitazin, Mancozeb, Propiconazole, Tebuconazole, Tebuconazole+Tricyclazole and Thiophanate methyl), found effective in vitro conditions were further evaluated in field.

Total seven effective botanicals were studied against Alternaria blight of Cluster bean under artificial inoculated field conditions at 20 per cent concentration. Results of pooled analysis in the (Table 1) revealed that minimum disease intensity $(15.98 \%)$ was recorded in Allium cepabulb extracts with highest yield of $26.66 \mathrm{q} / \mathrm{ha}$. It was significantly superior all the treatments. This was followed by $P$. hysterophorous leaf extract (20.01\%) and Cassia fistula (20.84 $\%$ ) with the yield of $23.81 \mathrm{q} / \mathrm{ha}$ and 23.34 $\mathrm{q} /$ ha respectively. Cassia torra leaf extract was found least effective as it gave $(31.51 \%)$ higher intensity with the minimum yield of $15.44 \mathrm{q} / \mathrm{ha}$. Eight effective fungicides were evaluated for management of Alternaria blight of Cluster bean at 0.1 per cent (systemic) and 0.2 per cent (non-systemic) concentrations by spraying twice at 15 days interval under artificial inoculated field conditions.

Two years pooled results on per cent disease intensity revealed that all the fungicides were significantly effective in reducing the Alternaria blight disease over control (Table $2)$. The minimum disease intensity $(14.50 \%)$ was recorded with the application of Carbendazim $(0.1 \%)+$ Mancozeb $(0.2 \%)$ with highest yield $26.33 \mathrm{q} / \mathrm{ha}$ as compared to other treatments of fungicides. 
Table.1 Effectiveness of botanicals and fungicides against Alternaria blight disease in Cluster bean during 2016 and 2017

\begin{tabular}{|c|c|c|c|c|c|c|}
\hline \multirow[t]{3}{*}{ Treatments } & \multicolumn{6}{|c|}{ Per cent disease intensity on leaves } \\
\hline & \multicolumn{3}{|c|}{2016} & \multicolumn{3}{|c|}{2017} \\
\hline & 45 DAS & $\begin{array}{l}75 \\
\text { DAS }\end{array}$ & $\begin{array}{l}\text { Yield } \\
(\mathrm{q} / \mathrm{ha})\end{array}$ & $\begin{array}{c}45 \\
\text { DAS }\end{array}$ & $\begin{array}{c}75 \\
\text { DAS }\end{array}$ & $\begin{array}{l}\text { Yield } \\
\text { (q/ha) }\end{array}$ \\
\hline Allium сера & $\begin{array}{c}7.58 \\
(15.9)\end{array}$ & $\begin{array}{l}15.35 \\
(23.0)\end{array}$ & $\begin{array}{c}26.2 \\
2\end{array}$ & $\begin{array}{c}8.53 \\
(16.9)\end{array}$ & $\begin{array}{l}16.60 \\
(24.0)\end{array}$ & 27.20 \\
\hline Azadirachtaindica & $\begin{array}{l}15.65 \\
(23.2)\end{array}$ & $\begin{array}{l}23.28 \\
(28.3)\end{array}$ & $\begin{array}{c}25.5 \\
5\end{array}$ & $\begin{array}{l}15.65 \\
(23.2)\end{array}$ & $\begin{array}{l}24.35 \\
(29.5)\end{array}$ & 24.44 \\
\hline Calotropisprocera & $\begin{array}{l}17.25 \\
(24.5)\end{array}$ & $\begin{array}{l}27.58 \\
(31.6)\end{array}$ & $\begin{array}{c}24.4 \\
4\end{array}$ & $\begin{array}{l}18.50 \\
(25.4)\end{array}$ & $\begin{array}{l}29.63 \\
(32.9)\end{array}$ & 22.27 \\
\hline Cassia fistula & $\begin{array}{l}11.30 \\
(19.6)\end{array}$ & $\begin{array}{l}20.28 \\
(26.7)\end{array}$ & $\begin{array}{c}24.1 \\
6\end{array}$ & $\begin{array}{l}12.48 \\
(20.6)\end{array}$ & $\begin{array}{l}21.40 \\
(27.5)\end{array}$ & 25.22 \\
\hline Cassia torra & $\begin{array}{l}23.30 \\
(28.8)\end{array}$ & $\begin{array}{l}30.50 \\
(33.5)\end{array}$ & $\begin{array}{c}24.9 \\
9\end{array}$ & $\begin{array}{l}24.55 \\
(29.6)\end{array}$ & $\begin{array}{l}32.53 \\
(34.7)\end{array}$ & 17.88 \\
\hline $\begin{array}{l}\text { Eucalyptus } \\
\text { globulus }\end{array}$ & $\begin{array}{l}21.40 \\
(27.5)\end{array}$ & $\begin{array}{l}31.48 \\
(34.1)\end{array}$ & $\begin{array}{c}23.8 \\
8\end{array}$ & $\begin{array}{l}22.40 \\
(28.2)\end{array}$ & $\begin{array}{l}31.48 \\
(34.1)\end{array}$ & 21.38 \\
\hline $\begin{array}{l}\text { Partheniumhystero } \\
\text { phorus }\end{array}$ & $\begin{array}{l}10.35 \\
(18.7)\end{array}$ & $\begin{array}{l}19.55 \\
(26.2)\end{array}$ & $\begin{array}{c}22.2 \\
7\end{array}$ & $\begin{array}{l}11.50 \\
(19.8)\end{array}$ & $\begin{array}{l}20.48 \\
(26.8)\end{array}$ & 25.55 \\
\hline Carbendazim & $\begin{array}{c}6.45 \\
(14.7)\end{array}$ & $\begin{array}{l}16.38 \\
(23.8)\end{array}$ & $\begin{array}{c}21.3 \\
8\end{array}$ & $\begin{array}{c}8.40 \\
(16.8)\end{array}$ & $\begin{array}{l}18.18 \\
(25.2)\end{array}$ & 26.00 \\
\hline $\begin{array}{l}\text { Carbendazim+ } \\
\text { Mancozeb }\end{array}$ & $\begin{array}{c}4.60 \\
(12.3)\end{array}$ & $\begin{array}{l}13.65 \\
(21.6)\end{array}$ & $\begin{array}{c}21.2 \\
2\end{array}$ & $\begin{array}{c}6.45 \\
(14.7)\end{array}$ & $\begin{array}{l}15.35 \\
(23.0)\end{array}$ & 27.44 \\
\hline Kitazin & $\begin{array}{l}25.20 \\
(30.1)\end{array}$ & $\begin{array}{l}29.60 \\
(32.9)\end{array}$ & $\begin{array}{c}27.4 \\
4\end{array}$ & $\begin{array}{l}27.40 \\
(31.5)\end{array}$ & $\begin{array}{l}31.35 \\
(34.0)\end{array}$ & 21.22 \\
\hline Mancozeb & $\begin{array}{c}8.55 \\
(16.99)\end{array}$ & $\begin{array}{l}16.58 \\
(24.0)\end{array}$ & $\begin{array}{c}17.8 \\
8\end{array}$ & $\begin{array}{c}9.63 \\
(18.0)\end{array}$ & $\begin{array}{l}17.30 \\
(24.5)\end{array}$ & 26.22 \\
\hline Propiconazole & $\begin{array}{l}22.48 \\
(28.2)\end{array}$ & $\begin{array}{l}32.48 \\
(34.7)\end{array}$ & $\begin{array}{c}17.4 \\
0\end{array}$ & $\begin{array}{l}23.73 \\
(29.1)\end{array}$ & $\begin{array}{l}31.25 \\
(33.9)\end{array}$ & 17.40 \\
\hline Tebuconazole & $\begin{array}{l}16.45 \\
(23.9)\end{array}$ & $\begin{array}{l}25.40 \\
(30.2)\end{array}$ & $\begin{array}{c}25.2 \\
2\end{array}$ & $\begin{array}{l}18.38 \\
(25.3)\end{array}$ & $\begin{array}{r}27.43 \\
(3.5)\end{array}$ & 23.88 \\
\hline $\begin{array}{l}\text { Tebuconazole+Tri } \\
\text { cyclazole }\end{array}$ & $\begin{array}{l}19.25 \\
(26.0)\end{array}$ & $\begin{array}{l}27.35 \\
(31.5)\end{array}$ & $\begin{array}{c}26.0 \\
0\end{array}$ & $\begin{array}{l}20.33 \\
(26.7)\end{array}$ & $\begin{array}{l}28.35 \\
(32.1)\end{array}$ & 24.16 \\
\hline $\begin{array}{l}\text { Thiophanate } \\
\text { methyl }\end{array}$ & $\begin{array}{l}13.48 \\
(21.5)\end{array}$ & $\begin{array}{l}21.50 \\
(27.6)\end{array}$ & $\begin{array}{c}27.2 \\
0\end{array}$ & $\begin{array}{l}14.50 \\
(22.3)\end{array}$ & $\begin{array}{l}23.40 \\
(28.9)\end{array}$ & 24.99 \\
\hline Control & $\begin{array}{l}33.50 \\
(35.3)\end{array}$ & $\begin{array}{l}44.35 \\
(41.7)\end{array}$ & $\begin{array}{c}16.3 \\
0\end{array}$ & $\begin{array}{l}35.38 \\
(36.4)\end{array}$ & $\begin{array}{l}48.58 \\
(44.1)\end{array}$ & 16.30 \\
\hline CD & 0.36 & 0.26 & - & 0.38 & 0.31 & - \\
\hline SE (m) & 0.12 & 0.09 & - & 0.13 & 0.11 & - \\
\hline
\end{tabular}

The value in parenthesis are angular transform. 
Table.2 Pooled data of effectiveness of botanicals and fungicides against Alternaria blight disease in Cluster bean during 2016 and 2017 in field management

\begin{tabular}{|c|c|c|c|c|c|}
\hline \multirow[t]{2}{*}{ Treatments } & \multirow{2}{*}{$\begin{array}{c}\text { Parts of } \\
\text { the } \\
\text { plant }\end{array}$} & \multirow{2}{*}{$\begin{array}{c}\text { Concentra } \\
\text { tion in Per } \\
\text { cent }\end{array}$} & \multicolumn{2}{|c|}{$\begin{array}{l}\text { Per cent disease } \\
\text { intensity }\end{array}$} & \multirow[t]{2}{*}{$\begin{array}{l}\text { Yield } \\
\text { (q/ha) }\end{array}$} \\
\hline & & & 45 DAS & 75 DAS & \\
\hline Allium cepa & Bulb & 20 & $\begin{array}{c}8.05 \\
(16.4)\end{array}$ & $\begin{array}{l}15.98 \\
(23.5)\end{array}$ & 26.66 \\
\hline Azadirachta indica & Leaf & 20 & $\begin{array}{l}15.65 \\
(23.2)\end{array}$ & $\begin{array}{l}23.81 \\
(29.1)\end{array}$ & 21.00 \\
\hline Calotropis procera & Leaf & 20 & $\begin{array}{l}17.88 \\
(24.9)\end{array}$ & $\begin{array}{l}28.60 \\
(32.3)\end{array}$ & 17.46 \\
\hline Cassia fistula & Leaf & 20 & $\begin{array}{l}11.89 \\
(20.1)\end{array}$ & $\begin{array}{l}20.84 \\
(27.1)\end{array}$ & 23.34 \\
\hline Cassia torra & Leaf & 20 & $\begin{array}{l}23.93 \\
(29.2)\end{array}$ & $\begin{array}{l}31.51 \\
(34.1)\end{array}$ & 15.44 \\
\hline Eucalyptus globulus & Leaf & 20 & $\begin{array}{l}21.90 \\
(27.8)\end{array}$ & $\begin{array}{l}31.48 \\
(34.1)\end{array}$ & 16.28 \\
\hline $\begin{array}{l}\text { Parthenium } \\
\text { hysterophorus }\end{array}$ & Leaf & 20 & $\begin{array}{l}10.93 \\
(19.2)\end{array}$ & $\begin{array}{l}20.01 \\
(26.5)\end{array}$ & 23.81 \\
\hline Carbendazim & - & 0.1 & $\begin{array}{c}7.43 \\
(15.7)\end{array}$ & $\begin{array}{l}17.28 \\
(24.5)\end{array}$ & 24.59 \\
\hline $\begin{array}{l}\text { Carbendazim+ } \\
\text { Mancozeb }\end{array}$ & - & $0.1+0.2$ & $\begin{array}{c}5.53 \\
(13.5)\end{array}$ & $\begin{array}{l}14.50 \\
(22.3)\end{array}$ & 26.33 \\
\hline Kitazin & - & 0.1 & $\begin{array}{l}26.30 \\
(30.8)\end{array}$ & $\begin{array}{l}30.48 \\
(33.4)\end{array}$ & 14.67 \\
\hline Mancozeb & - & 0.2 & $\begin{array}{c}9.09 \\
(17.5)\end{array}$ & $\begin{array}{l}16.94 \\
(24.2)\end{array}$ & 25.55 \\
\hline Propiconazole & - & 0.1 & $\begin{array}{l}23.10 \\
(28.7)\end{array}$ & $\begin{array}{l}31.86 \\
(34.4)\end{array}$ & 14.65 \\
\hline Tebuconazole & - & 0.1 & $\begin{array}{l}17.41 \\
(24.6)\end{array}$ & $\begin{array}{l}26.41 \\
(30.1)\end{array}$ & 20.05 \\
\hline $\begin{array}{l}\text { Tebuconazole+ } \\
\text { Tricyclazole }\end{array}$ & - & $0.1+0.1$ & $\begin{array}{l}19.79 \\
(26.4)\end{array}$ & $\begin{array}{l}27.85 \\
(31.8)\end{array}$ & 18.79 \\
\hline Thiophanate methyl & - & 0.1 & $\begin{array}{l}13.99 \\
(21.9)\end{array}$ & $\begin{array}{l}22.45 \\
(28.2)\end{array}$ & 22.10 \\
\hline Control & & & $\begin{array}{l}34.44 \\
(35.9)\end{array}$ & $\begin{array}{l}46.46 \\
(42.9)\end{array}$ & 12.78 \\
\hline CD & & & 0.83 & 1.05 & - \\
\hline SE (m) & & & 0.27 & 0.34 & - \\
\hline
\end{tabular}

The value in parenthesis is angular transformed 
Figure.1 Pooled data of effectiveness of botanicals and fungicides against intensity of Alternaria blight disease in Cluster bean during 2016 and 2017 in field management

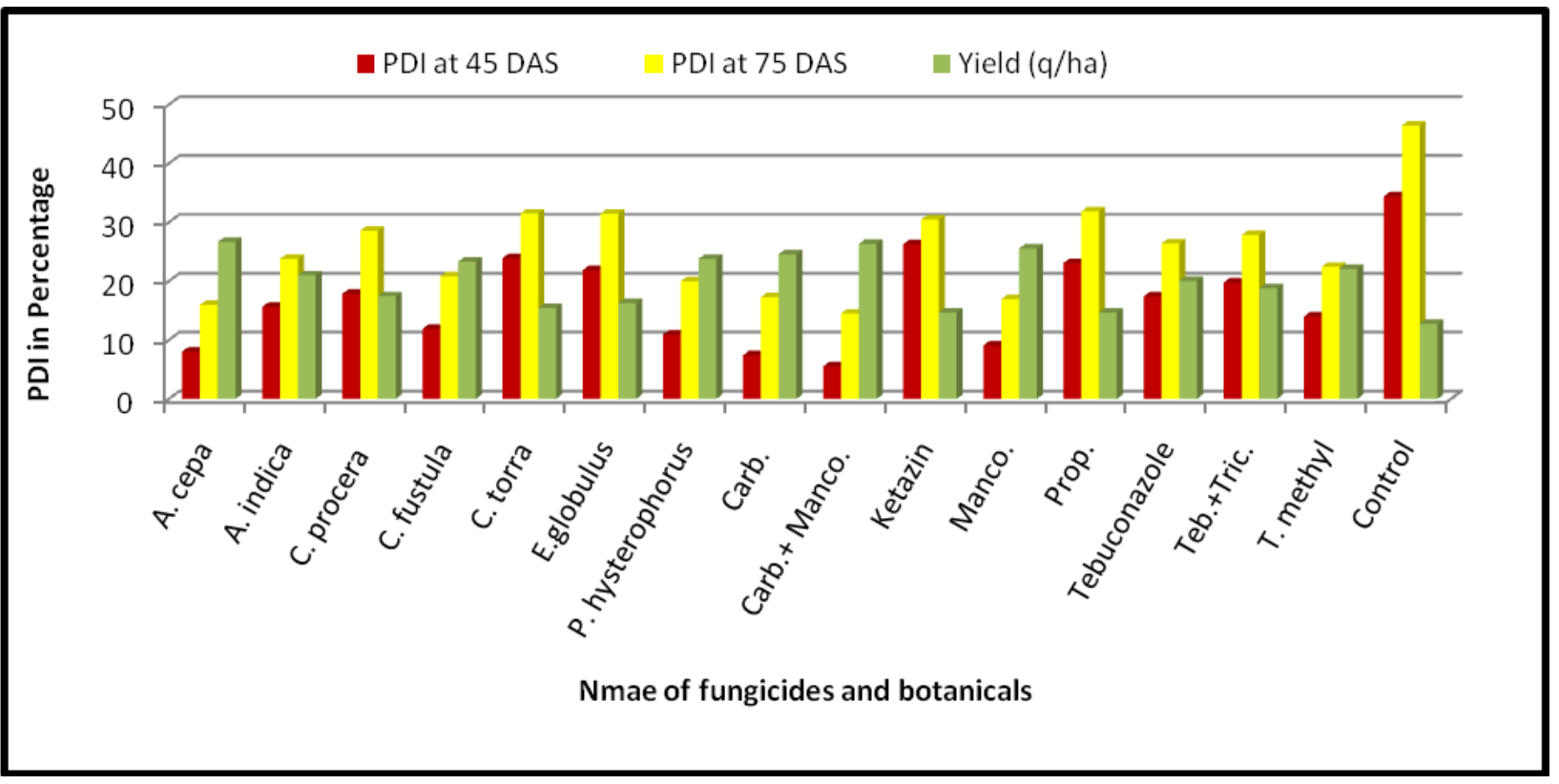

Plate.1 Field evaluation of selected botanicals and chemicals against growth of A.c. var. Cyamopsidis of Cluster bean

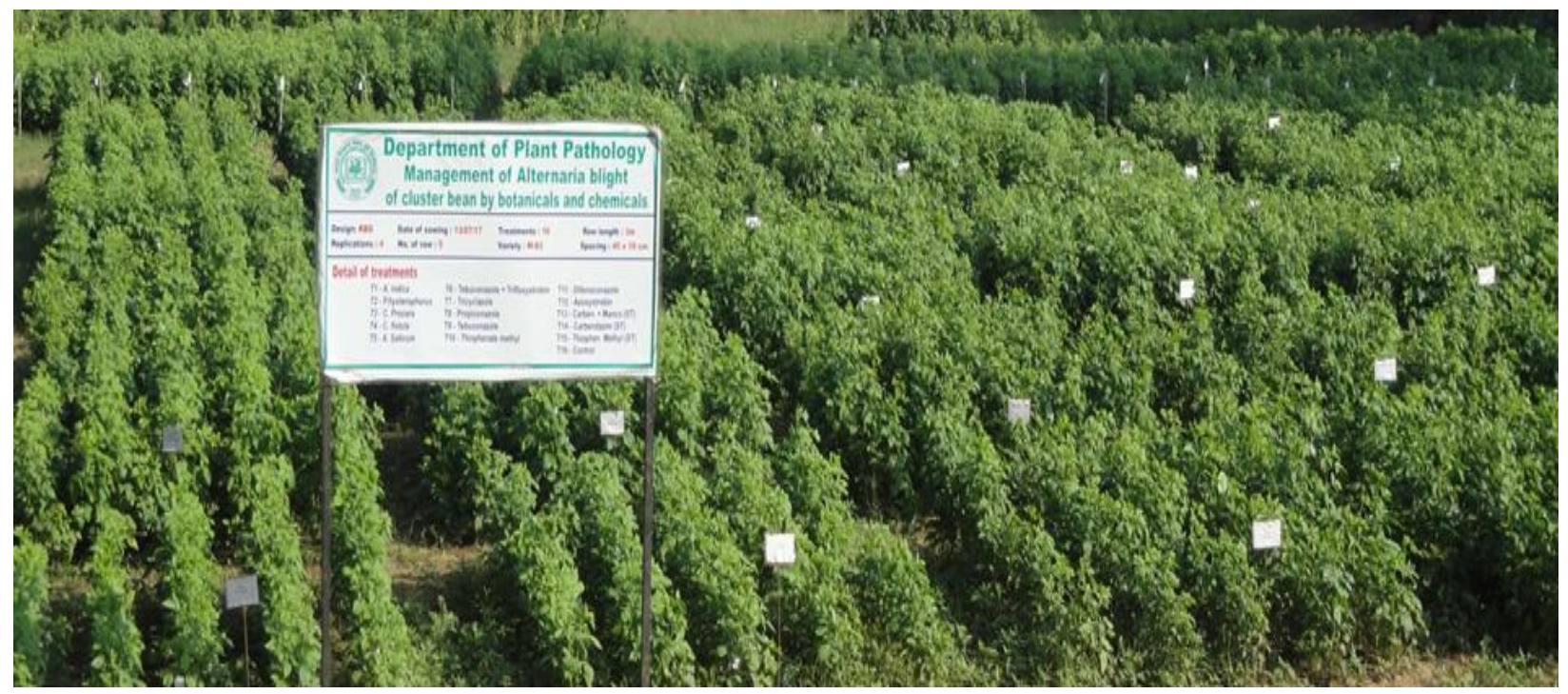

However, Mancozeb (0.2\%)) was observed to be second best with 16.94 per cent disease intensity with second highest yield of 25.55 $\mathrm{q} / \mathrm{ha}$. Propiconazole $(0.1 \%)$ was found least effective with 31.86 per cent disease intensity with the lowest yield of $14.65 \mathrm{q} / \mathrm{ha}$. The two year pooled data showed that the different treatments increase the two times yield of Cluster bean over control (Figure 1 and Plate 1).

The effective botanicals @ 20\% and fungicides@0.2 per cent concentration were further evaluated in the field study. Allium 
cepa showed minimum intensity against Alternaria blight disease and showed maximum yield. The maximum PDI and minimum yield of Cluster bean was found in Cassia tora. Carbendazim+Mancozeb combination showed the minimum PDI against Alternaria blight disease and maximum yield was obtained by this combination.

Hence, the application of eco-friendly chemicals can provide good control of Alternaria blight. The various workers had been tested fungicides and botanicals under field condition (Kandolo et al., 2016; Reuveni et al., 2002; Ingle et al., 2014; Kumar et al., 2005; Patil and Nargund, 2017).

A number of plant species have been reported to possess some natural substances in their leaves which were toxic to many fungi causing plant disease (Spencer et al., 1957; Egawa et al., 1977; Mishra and Dixit, 1976; Shekhawat and Prasad, 1971; Tripathi and Dixit, 1981).

The present investigation revealed that lowest inhibition percentage was recorded in $P$. hysterophorus. But, found that the leaf extracts of $P$. hysterophorus, Calotropis procera and Azadirachta indica distinctly reduced the growth of $A$. brassicae, P.hysterophorus and A. indica. They were found to be most effective in reducing percent disease intensity of Alternaria. The highest yield was also obtained in $P$. hysterophorus treated plots followed by $D$. stramonium (Tiwari et al., 2000).

Aqueous leaves extract of Parthenium hysterophorus, Annona reticulata, Polyalthia longifolia, Ipomea carnea, Tridax procumbens, Argemone mexicana, Cathranthus roseus, Eucalyptus globulusand Achyranthus aspera were used against the post-harvest fungal mycoflora. All the plants used were found to be antifungal. In particular Eucalyptus globulus, Argemon emexicana, Tridax procumbens and Parthenium hysterophorus were highly inhibitory (Mogle, 2013).

It is concluded in the field study, Allium cepa leaf extract @ 20\% concentration and Carbendazim (0.1 per cent) + Mancozeb (0.2 per cent) concentration were found very effective in reducing Alternaria blight and enhancing the yield of Cluster bean. The leaf extract of botanicals seems to be an alternate to the fungicides for an eco-friendly management of Alternaria blight disease.

\section{Acknowledgement}

The authors are grateful to Dean, college of Agriculture, Gwalior, for providing the field and lab facility for the research work.

\section{References}

Akbari, L.F. and Parakhia, A.M. (2007). Management of Alternaria alternate causing blight of sesame with fungicides. J. Mycol. Pl. Path. 37(3): 426-430.

Amaresh, Y. S. (2000), Epidemiology and management of Alternaria leaf blight and rust of sunflower (Helianthus annus L.). Ph.D. Thesis, Univ. Agric. Sci., Dharwad, Karnataka, India.

Ambesh, B.S. Ngomle, S. Marak, T. and Das, S. (2014). Morphological and biochemical variation of some Alternaria species infected on different floricultural plants. The Ecoscan. 4(4): 361-368.

Behairy, A., Magda H., Sobhy, H.M., Abbas, M.S., Abada, A. and Medhat, Y. (2014). Alternaria leaf spot disease control on Faba bean in Egypt. J. Pl. Protect. Path., 5(1): 119-130.

Dubey, S.C. (2002). Evaluation of 
Gliocladium virens and Trichoderma viride as foliar spray against web blight of urd and mung bean. J. Mycl. Pl. Path.32: 407-410.

Dubey, S.C. Patel, B. and Jha, O.K. (2000). Chemical management of Alternaria blight of broad bean. Indian Phytopath. 53(2): 2I3-2I5

Egawa, H. Tsutsui, O. Tatsuyama, K. and Hatta, T. (1977). Antifungal substances found in leaves of Eucalyptus sp. Experientia, 33: 889-890.

Gaur, R.B. and Ahmed, S.A. (1983). Studies on chemical control, source of resistance and survey of Alternaria leaf spot of clusterbean. Forage Res., 9: 179 $-180$.

Ginoya, C.M. and Gohe, N.M.L. (2015). Evaluation of newer fungicides against Alternaria alternate (Fr.) Keissler causing fruit rot disease of chilli. Int. J. Pl. Protect. 8(1): 169-173.

Godara, S.L. and Pathak, V.N. (1995). Effect of plant extracts on post-harvest rotting of sweet orange fruits. Indian J. Mycol. Pl. Path. 25(1\& 2): 34-35.

Grange, N. and Ahmed, S. (1988). Handbook of Plants with Pest Control Properties. John Wiley and Sons, New York.

Gupta, P., Gupta, P.P. and Gupta, S.K. (1999). Efficacy of different fungicides on the management of Alternaria leaf spot of clusterbean and their influence on different oxidative enzymes. $\mathrm{Pl}$. Dis. Res. 14(2): 182-186

Gupta, V. (1997). Management of Alternaria leaf spot in guar. M.Sc. Thesis, CCS HAU, Hissar India, 60, pp.

Hiremath, P.C. and Sundaresh, H.N. (1985) Fungicidal control of Alternaria leaf blight of soybean in Karnataka State. Pesticides., 19:15-16.

Hussaini, S.H. and Singh, H. (1989).Efficacy of different fungicides against Alternaria blight of radish seed crop.Pl. Dis. Res. 4: 105 - 107.
Ingle Y. V. Patil C. U. Thakur, K. D. and Ingle Kalyani. (2014). Effect of fungicides and plant resistance activator on Colletotrichum leaf spot of Soybean. The Bioscan. 9(3): 1187-1190.

Jagannathan, R. and Narasimhan, V. (1988). Effect of plants extracts/ products on two fungal pathogens of Finger millet. Indian J. Mycol. Pl. Path. 18: 250-254.

Jain, J.P. and Patel, P.N. (1969). Effects of fungicides on the seed mycoflora of guar, their role in emergence and vigour of seedlings and efficacy of fungicides. Indian Phytopath. 22: 245-250.

Jeeva, M.L. and Ramabadran, L. (1992). Effect of plant products on the management of Sarocladium oryzae (Sawada) W. Gams and D. Hawksw and Fusarium oxysporum f sp. Lycopersici (Sacc.) Sayder and Hansen. Madras Agricult. J. 79: 488-491.

Kanwar, K. Yadav, S.S. Verma, H.P. Yadav, L.R. and Shivran, A.C. (2016). Effect of weed control methods and phosphorus fertilization on growth and yield of clusterbean. Ann. Agric. Res. New Series, 37(3): 290-294.

Kandolo, S.D., Thompson, A.H., Calitz, F.J., Laurie, S.M., Truter, M., Van Der, J.E., Waals and Aveling, T.A.S. (2016). Field tolerance of selected varieties and fungicide efficacy against Alternaria blight of sweet potato. African Crop Sci. J. 24(3): $331-339$.

Kirk, W.W. Flecher, D.S. Douchs, J.M. Coombs, K.M., Hammerschmidt, R. (2001). Effect of host plant resistance and reduced rates and frequency of fungicides application to control potato late blight. Plant Dis.85:1113-1118.

Kumar, A. (1998). Evaluation of some plant extracts against Alternaria brassicae (Berk.) Sacc. J. Oilseed Res., 15(1): 198-199.

Kumar, A. and Sachan, S.N. (1979). Effect of some plant extracts on the conidial 
germination of Curvularia pallescens. Indian Phytopath.32:489.

Kumar, A. Thakur, K.S. Thakur, H.L. and Kumar, A. (1996).Cultural management of yield losses due to Alternaria blight in mustard in Brassica. Himachal $J$. Agric. Res.22(1 \& 2): 36-39.

Kumar, S., Upadhyay, J. P. and Kumar, S. (2005). Evaluation of plant extracts for control of Alternaria Leaf spot of Viciafaba. Ann. Pl. Protect. Sci., 13(1): 213-269.

Lal, H. C. Upadhyay, J. P. and Ojha, K.L. (1998).Management of Alternaria Leaf blight of pigeonpea through plant extract and chemical of plant origin. $J$. Appl. Biol.9: 81-83.

Mane, V.A. Rite, S.C., Medhe, N.K. Gaikwad, R.D. and Belwadkar, V.N. (2011).Management of Alternaria alternata(Fr.) Keissler causing blight of chilli (Capsicum annum L.). Green Farming, 2(4): 485-486.

Mathivanan, N. Prabavathy, V.R. (2007).Effect of Carbendazim and Mancozeb combination on Alternaria leaf blight and seed yield of sunflower. Pl. Protect. 40(2): 90-96.

Meena, A.K., Godara, S.L. and Gangopadhyay, S. (2010). Efficacy of fungicides and plant extracts against Alternaria blight of clusterbean .J. Mycol. Plant Path.40(2): 222-226.

Mishra, S.B. and Dixit, S.N. (1976). Fungicidal spectrum of the leaf extract of Allium sativum. Indian Phytopath.29: $448-449$.

Mogle U.P. (2013). Efficacy of leaf extracts against the post-harvest fungal pathogens of cowpea. Biosci. Discov. 4(1): 39-42.

Namanda, S. Olanya, O.M. Adipala, E. Hakiza, J.J. and Bedewy, R.E. (2004). Fungicide application and host resistance for potato late blight management: benefits assessment from on-farm studies in S.W. Uganda. Crop Protect.23: 1075-1083.

Nandagopal, V. and Ghewande, M.P. (2004).Use of Neem products in groundnut pest management in India. Nat. Prod. Radi., 3(3): 150-155.

Nene, Y.L. and Thapliyal, P.N. (1993). Fungicides in plant disease control. Oxford and IBM, New Delhi. pp. 579.

Patel, R.C. (2008). Studies on fruit rot (Alternaria alternataFr. Keissler) of chilli (Capsicum annum L.) and its management. M.Sc. (Ag.) Thesis, Anand Agricultural University, Anand (Gujrat) India.

Patil, S. and Nargund, V.B. (2017).Field efficacy of chemicals for the management of Twister disease of onion.Int. J. Agric. Sci. Res.7(1): 343346.

Rakesh, A.S. Rathi Kumar Anil and Hawa, Singh. (2016). Evaluation of fungicides for the control of Sclerotinia stem rot of Indian mustard caused by Sclerotinia sclerotiorum(Lib.) de Bary. J. Appl. Natural Sci. 8(1): $441-444$.

Reuveni, M. Sheglov, D. Sheglov, N., BenArie, R. and Prusky, D. (2002).Sensitivity of red delicious apple fruit at various phonologic stages to infection by Alternaria alternate and moldy-core control. European $\mathrm{J} . \mathrm{Pl}$. Path, 108: 421-427.

Roy, B., Amin, R., Uddin, M. N., Islam A. T. M. S., Islam, M. J. and Halder, B. C. (2005). Leaf extracts of Shiyalmutra (Blumealacera) as botanical pesticides against lesser grain borer and rice weevile. J. Biol. Sci. 5(2): 201-204.

Sharma, S. R. (1983). Effect of fungicides on the development of Alternaria blight and yield of clusterbean. Indian $J$. Agric. Sci.53(11): 932-935.

Shekhawat, P.S. and Prasad, R. (1971). Antifungal properties of some plant extracts, inhibition of spore 
germination. Indian Phylopathol. 24: 800-803.

Shivapuri, A., Sharma, O. P. and Jharuavia, S. L., (1997). Fungitoxic properties of plant extracts against pathogenic fungi. J. Mycol. Pl. Path, 27: 29-31.

Singh, H.K., Kavita, Singh, R.B. and Maurya, K.N. (2014) Management of Alternaria blight of Indian mustard through resistance inducing chemicals. J. Agric Res. 1(2): 108-111.

Singh, J. and Majumdar, V.L. (2001). Efficacy of plant extracts against Alternaria alternata - the incitant of fruit rot of pomegranate (Punicagranatum L.). J. Mycol. Pl. Path. 31: 346-349.

Singh, P., Singh, A.K. and Singh, R.N. (2003). Effect of Neem products on the growth of Alternaria triticina. Ann. Pl. Protec. Sci. 11(2): 369-410.

Singh, R.B. and Singh, R.N. (2004). Occurrence and management of Alternaria blight of linseed in eastern. India. Pl. Dis. Res. 19:120-124.

Singh, S.D. and Prasad, R. (1972). Studies on physiology and control of Alternaria cyamopsidis the incitant of blight disease of guar. Indian J. Mycol. Plant Path. 3: $33-39$.

Spencer, D.M., Topps, Omd J.H. and Wain, R.L. (1957). Fungistatic properties of antifungal substances from the tissue of Viciafaba. Nature, 179: $651-652$.

Swami, C.S. and Alane, S.K. (2013).Efficacy of some botanicals against seed - borne fungi of green gram (Phaseolus aureusroxb.). Biosci.Dis.4(1): 107-110.

Thangamani, J. and Narayanaswamy, K. (1998). Role of neem products in the control of fungal disease of rice. Nat. Seminar on Management of crop disease with plant products/Biological agents. J. Tamil Nadu Agri. Univ. Madurai. 6: 11-12.

Tiwari, S.N., Shukla, H.S., Biswal, M.M. and Nayak, M. (2000). Fungitoxic properties of some leaf extracts. Nat. Acad. Sci. Lett. 11: 369 - 373.

Tomar, D.S., Singh, R. and Shastry, P.P. (2005).Management of Alternaria blight of clusterbean through agro-chemicals. JNKVV Res. J. 38(1): 86-89.

Tripathi, R.D. and Dixit, S.N. (1981). Fungitoxicity of lawsone, isolate from the leaves of Lawsonia inermis and some related nepthoqllinones of angiosperm origin. Proc. $3^{\text {rd }}$ Internat. Symp. Pl. Pathol.., IARI New Delhi.

Usman, M.R.., Jaganathan, R. and Diankaran, D. (1991). Plant disease management on groundnut with naturally occurring plant products. Madras Agric. J.78:15253.

Yogi, R. Sharma, O.P. Verma, H.P. Kanwar, K. and Shivran, A.C. (2016).Response of fertility and agro-chemical on growth and yield of different varieties of clusterbean. Ann. Agric. Res. New Series, 37(3): 295-299.

\section{How to cite this article:}

Satish Sharma, Reeti singh and Ajay Kumar. 2020. Field Evaluation of Selected Botanicals and Fungicides for the Management of Alternaria Blight of Cluster Bean. Int.J.Curr.Microbiol.App.Sci. 9(07): 1045-1053. doi: https://doi.org/10.20546/ijcmas.2020.907.122 